\title{
Standardization of the exclusion criteria for the HTLV I and II in brazilian eye banks
}

\author{
Padronização do critério de exclusão para o \\ vírus HTLV I e II nos bancos de olhos do Brasil
}

Gyanna Lys de Melo Moreira Montenegro', Daniel Alves Montenegro², Antônio Moreira Montenegro³, Jamili Anbar Torquato ${ }^{4}$

\begin{abstract}
Objective: Investigate in which eye banks in Brazil the HTLV I and II is used as exclusion criteria for cornea. Nowadays Brazilian Legislation, through Law $n^{\circ}$ 9.434/97 and Ordinance 2600/09 determines that for each donation, laboratory screening tests of high sensibility must be done mandatorily for detection of markers of infectious diseases transmissible by blood: Human Immunodeficiency Virus (HIV), Hepatitis B Virus (HbsAg), Antibody of the Hepatitis B Virus (AntiHBs), Antibody of total Hepatitis B Virus (total Anti$H B c$ ) and Hepatitis C Virus (Anti-HCV), however, paragraph a of Chapter VI, Art. 47 excludes the HTLV as exclusion criteria for cornea donors. Methods: For the realization of this research, information from 35 eye banks was analyzed, through the database of the Transplant Central of Paraiba, evaluated through the Chi-Square Homogeneity Test. Results: It was observed that the positive serology for HTLV I and II was considered exclusion criteria in 18 of the 35 eye banks analyzed. In relation to the geographic analysis of the Eye Banks in Brazil, the ones in the Northeastern and Southern regions were the ones that most considered the HTLV as exclusion criteria. Conclusion: The analyzed Eye Banks did not present difference or significant association between the ones that consider and the ones that do not consider this criterion, showing, this way, that there is not a standardization among the Eye Banks in Brazil.
\end{abstract}

Keywords: Tissue donors; Cornea; Eye banks/standards; Human T-lymphotropic virus 1

\section{ResUMO}

Objetivo: Investigar em quais Bancos de olhos do Brasil o HTLV I e II é utilizado como critério de exclusão para córnea. Atualmente a legislação brasileira pela Lei n ${ }^{\circ}$ 9.434/97 e Portaria 2600/09 determina que a cada doação devem ser realizados, obrigatoriamente, testes laboratoriais de triagem de alta sensibilidade, para detecção de marcadores para doenças infecciosas transmissíveis pelo sangue: Vírus da Imunodeficiência Humana (HIV), Vírus da Hepatite B (HbsAg), Anticorpo do Vírus da Hepatite B (AntiHBs), Anticorpo do Vírus da Hepetite B total (Anti-HBc total) e Vírus da Hepatite C (Anti-HCV), no entanto, o Capítulo VI, art. 47, alínea a exclui o Vírus Linfotrópico das Células T-Humanas (HTLV) como critério de exclusão para doadores de córnea. Métodos: Para a realização da pesquisa, foram analisadas as informações de 35 Bancos de Olhos pela base de dados da Central de Transplante da Paraíba, avaliados através do Teste de Homogeneidade do Qui-Quadrado. Resultados: Constatou-se que a sorologia positiva para HTLV I e II foi considerada critério de exclusão em 18 dos 35 Bancos de Olhos analisados. Quanto à análise geográfica dos Bancos de Olhos do Brasil, os da região Nordeste e Sul foram os que mais consideraram o HTLV como critério de exclusão. Conclusão: Os Bancos de Olhos analisados não apresentaram diferença ou associação significativa entre os que consideram e os que não consideram este critério, mostrando, desta forma, não haver uma padronização entre os Bancos de Olhos do Brasil.

Descritores: Doadores de tecidos; Córnea; Bancos de olhos/normas; Vírus 1 linfotrópico T humano

\footnotetext{
${ }^{1}$ Ambulatory of Nephrology, University Hospital Lauro Wanderley, Federal University of Paraíba, João Pessoa, PB, Brazil; Transplantation Center of Paraíba - CNCDO/PB, João Pessoa, PB, Brazil.

${ }^{2}$ Vision Treatment Center - João Pessoa, PB, Brazil.

${ }^{3}$ Residence Program in Ophthalmology, Clinical Hospital, Federal University of Pernambuco, Recife, PE, Brazil.

${ }^{4}$ University of Cruzeiro do Sul, São Paulo, SP, Brazil.
}

Work carried out at the Transplantation Center of Paraíba - CNCDO/PB - João Pessoa, PB, Brazil.

The authors declare no conflicts of interests.

Received for publication 24/11/2014 - Accepted for publication 02/08/2015 


\section{INTRODUCTION}

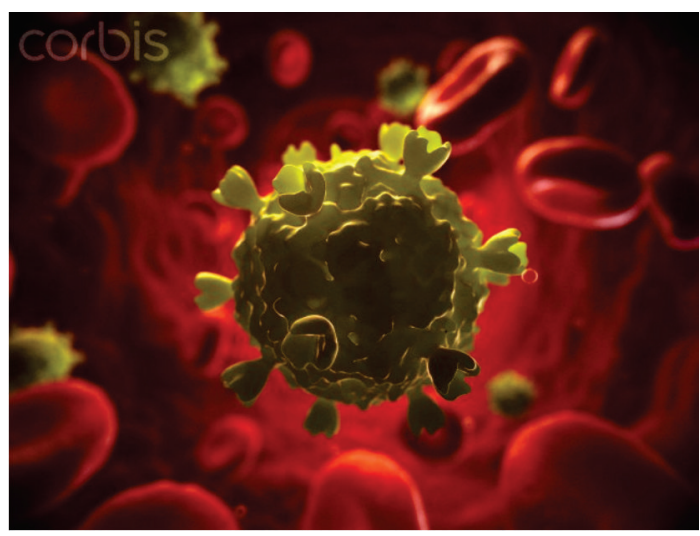

Figure 1: HTLV Virus.

Source: Sciepro/Science Photo Library/Corbis ${ }^{1}$

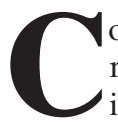

orneal diseases are the second most common cause of reversible blindness in the world ${ }^{2}$, representing an important cause of loss of visual capacity, which may lead to psychological and economic consequences for the individual and society ${ }^{3}$.

Such diseases reach a young and active population, leading to an important economic and social loss ${ }^{2,3}$. The lack of donated tissue and eye banks able to supply corneas in number and quality suitable for transplants is a reality, despite the efforts ${ }^{2}$.

It is necessary to point out that the development of surgical techniques and the improvement in the results obtained by corneal transplant surgery in recent years led to greater expectations of visual rehabilitation to people who did not have another option for recovery ${ }^{2}$.

However, it is necessary to point out that in some developing countries it is difficult to have access to ophthalmologic assistance due to both socioeconomic and cultural factors, as well as obstacles imposed by the insufficient health system ${ }^{2}$.

There are still other factors that influence the transplant process, the serologic tests and the exclusion criteria used by the eye banks of Brazil. It was observed that there is a divergence in Ordinance 2600/2009 regarding the Human T-Lymphotropic Virus (HTLV), and for organs and other tissues it is considered an exclusion criteria, but for cornea this criterion is not used.

In this situaiton, the objective of this study was to investigate in which Eye Banks in Brazil the HTLV I and II is used as an exclusion criteria for cornea by means of the analysis of information from the Transplant Center of Paraíba.

The HTLV virus infection is a disease that infects the body's defense cells, the T lymphocytes. Transmission occurs in the same way as HIV (Human Immunodeficiency Virus) ${ }^{4}$.

The HTLV induces polarizing events of the cells, which provides the join of infected and uninfected cells, facilitating the passage of the virus. This process is called "viral-induced synapse"

This article proposes that the Human T-cell Lymphotropic Virus (HTLV) I and II is adopted as an exclusion criteria in cornea donations, standardizing the procedure of Ordinance 2600/ 09 in its chapter VI, Art. 47, Item II, paragraph a.

\section{MethodS}

This is a review of forty-eight (48) Eyes Banks registered in the National Transplant System (SNT), based on their geographical distribution and their positioning on the use of HTLV as the exclusion criteria for cornea transplant.

The information of thirty five (35) banks distributed in the five regions of the country has been extracted from the database of the Transplant Center of Paraíba after the approval by the Ethics Committee of University Hospital Lauro Wanderley/ UFPB: CAAE: 34859214.7.0000.5183.

The Chi-square Homogeneity test was used, equivalent to the comparison test of two proportions, because it is a sample with dichotomous categorical variable (yes/no) with a significance level of $5 \%(0.05)$.

\section{Results}

The present study shows that the comparison in the percentage of eyes banks that exclude the HTLV virus in the donation of cornea and those who do not exclude the HTLV, i.e., 18 eye banks (51\%) x 17 eye banks (49\%) by means of the Chi-square homogeneity test showed no significant difference between the proportions of answers "Yes x No", as shown in Figure 2:

\section{Exclusion criteria of HTLV ( $n=35)$}
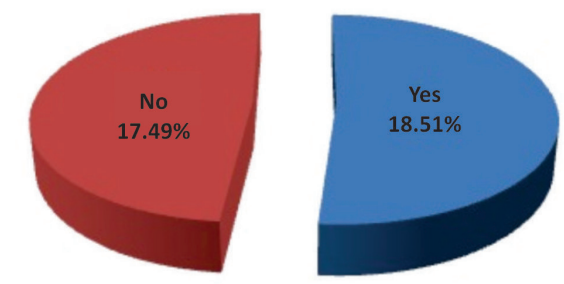

Figure 2. Exclusion of HTLV in cornea donations

From the information of the Transplant Center of Paraíba it was found that in 35 Eye Banks distributed in the five regions of Brazil the exclusion criteria of HTLV virus for cornea is as the data shown in table 1.

Figure 3 shows the joint distribution of the exclusion criteria of HTLV virus for corneal donations in five regions of Brazil, thus distributed in the North $(4 ; 11.4 \%)$, Northeast $(7 ; 20.0 \%)$, Midwest $(2 ; 5.7 \%)$, Southeast $(11 ; 31.4 \%)$ and South $(11 ; 31.4 \%)$. From the total of $n=35(100 \%), 18$ eye banks $(51.0 \%)$ answered yes to this exclusion criteria, while 17 eye banks $(49.0 \%)$ answered no.

\section{Table 1}

\section{Exclusion criteria of HTLV according to the five regions of Brazil}

\begin{tabular}{|c|c|c|c|c|c|c|}
\hline \multirow{3}{*}{$\begin{array}{l}\text { Regions of } \\
\text { the country }\end{array}$} & \multicolumn{6}{|c|}{ Exclusion criteria (HTLV) } \\
\hline & \multicolumn{2}{|c|}{ Total } & \multicolumn{2}{|c|}{ Yes } & \multicolumn{2}{|c|}{ No } \\
\hline & $\mathbf{n}$ & $\%$ & $\mathbf{n}$ & $\%$ & $\mathbf{n}$ & $\%$ \\
\hline - North & 4 & 11.4 & 2 & 11.1 & 2 & 11.8 \\
\hline - Northeast & 7 & 20.0 & 4 & 22.2 & 3 & 17.6 \\
\hline - Midwest & 2 & 5.7 & 1 & 5.6 & 1 & 5.9 \\
\hline - Southeast & 11 & 31.4 & 4 & 22.2 & 7 & 41.2 \\
\hline - South & 11 & 31.4 & 7 & 38.9 & 4 & 23.5 \\
\hline Total & 35 & 100 & 18 & 100 & 17 & 100 \\
\hline
\end{tabular}




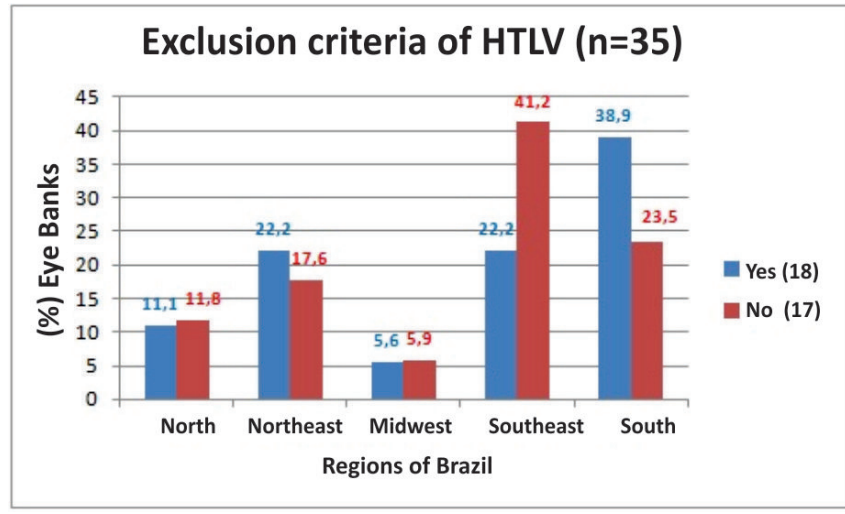

Figure 3: Eye Banks in the regions of Brazil - exclusion of HTLV

\section{Discussion}

According to Law No 9434 of February 4, 1997 which provides for the removal of organs, tissues and human body parts for transplant purposes, "to carry out transplants or grafts of tissue, organ and parts of human body can only be authorized after the donor has made all the screening tests for diagnosis of infection (...)"'6.

Created by Ordinance $902 / \mathrm{GM}$ of $08 / 16 / 2000^{7}$ within the Unified Health System (SUS), the Eye Banks have as one of its competencies to carry out the laboratory tests needed to identify possible contraindications for the use of donated corneas, assuring the quality of the eye tissues distributed.

In these tests, the screening of HTLV I and II is excluded when it comes to the corneal tissue, allowing a divergence of procedure between the Eye Banks ${ }^{8}$.

There is a discussion about the risk of transmission of HTLV associated with the cornea transplantation ${ }^{9}$. About this risk, Salahuddin et. Al. ${ }^{10}$ have reported the isolation of human $\mathrm{T}$ cells in the epithelium of the cornea of a potential donor. In said report, the scientists rely on demonstration that the virus is present in the tears and the conjunctival epithelium in patients with AIDS, and they considered that this is evidence of the widespread distribution of the virus. It is still unknown if deeper eye structures can accommodate the virus. In this research, the authors did not detect viruses in the stroma of the cornea, nor in keratinocytes $r$ endothelium, but they acknowledged that it is prudent to consider these tissues as possible sites for infection until more definitive studies are carried out.

But the study of the European Centre for Disease Prevention and Control (ECDC) $)^{11}$ raises the question about the procedure in which the donor tissue is thoroughly washed and kept in a tissue culture for an extended period before use, reducing the adhesion of lymphocytes and the risk of the transmission of HTLV occuring via cornea transplant, allowing to consider the risk as extremely remote.

$\mathrm{O}^{\prime} \mathrm{Day}^{12}$ reports that the amount of virus present in the tissue is an infecting inoculum, but it is unknown how many corneal donors carry out this virus, as well as whether the infection is possible by menas of transplant. While there is no proven case of infection after keratoplasty, it would be premature to disconsider the risk or consider it minimal or non-existent.

Regarding their geographical distribution, the HTLV virus, according to the research of Portela ${ }^{13}$, has a higher prevalence in Central Africa, in different areas of Europe, North America, and
South America, including Brazil. Among the Brazilian states, the HTLV has manifested with a higher incidence in Bahia, as well as in Rio de Janeiro, Pará and Rio Grande do Sul. As a suggestion, Thomas et. al. ${ }^{14}$, in a study conducted in the United Kingdom, propose that while it is not possible to carry out reliable tests for the detection of HTLV, it may be implemented a policy in which patients can be informed about the nature and manifestations of the disease, its possibility of transmission through the corneal transplant, and so they can decide whether they accept corneas that weren' selected for HTLV. This would be an alternative until the problem is solved.

$\mathrm{APABO}^{15}$, a member-founder of the Global Alliance of Eye Bank Associations (GAEBA), along with six international associations of Eye Banks, is working on unifying the standards. The "International Medical Standards for the Eye Banks" Will soon be formalized with the support of the World Health Organization (WHO).

Currently, according to the Medical Standards of APABO, for the provision of eye tissues the presentation of non-reagents final results in the detection tests for hepatitis $\mathrm{B}$, hepatitis $\mathrm{C}$ and HIV-1 and HIV-2 $2^{16}$ is mandatory. Soon said standards will include the completion of lab tests for HTLV I-II as a criteria required in donor screening. to the extent that with the publication soon of the new RDC for Tissue Banks the tests will be required for ocular tissues ${ }^{16}$.

The International Classification of a unique identification system for donors will be increasingly important for surveillance and traceability in transnational export of human cells and tissues ${ }^{17}$. There is always an opportunity for quality improvement with keeping constant watch ${ }^{17}$.

It is important to remember that AIDS epidemic has already presented many challenges for medicine, so we can't ignore the risks of the virus HTLV. Such questioning leads us to look carefully to the safety of our patients, while we strive to eliminate any risk possibility.

\section{Conclusion}

The test results indicate the lack of standardization in the Eye Banks of Brazil, in relation to considering or not the HTLV I and II as an exclusion criteria for the cornea, requiring the inclusion of corneas among the same criteria of other tissues, which will ensure their quality and their universal use.

Therefore, we conclude that there is a predominance among the 35 eye banks examined in considering or not the exclusion criteria in HTLV donations of cornea. Note that the eye banks in the Northeast are the ones which use the most HTLV as an exclusion criteria, while the eye banks in the Southeast are the ones which least consider this criteria.

\section{ACKNOWLEDGEMENTS}

To José Josinaldo Félix Vieira Júnior e a Manuela Mariz Nóbrega, from the Transplant Center of Paraiba.

\section{REFERENCES}

1. Brasil. Ministério da Saúde. Blog da Saúde. HTLV, o parente desconhecido do HIV. [citado 2015 Ago 29]. Disponível em www.blog.s a ud e.gov.br/i mages/s a ude e m dia/ VirusSciepro_SciencePhotoLibrary_Corbis.jpg. 
2. Almeida HG, Souza AC. Perfil epidemiológico de pacientes na fila de transplante de córnea no estado de Pernambuco - Brasil. Rev Bras Oftalmol. 2014; 73(1):28-32.

3. Kara-Junior N, Mourad PC, Espíndola RF, AbilRuss HH. Expectativas e conhecimento entre pacientes com indicação de transplante de córnea. Rev Bras Oftalmol. 2011; 70(4): 230-4.

4. Glasser DB. Serologic testing of cornea donors. Cornea. 1998;17(2):123-8.

5. Bangham CR. The immune control and cell-to-cell spread of human T-lymphotropic virus type 1. J Gen Virol. 2003; 84(Pt 12):3177-89. Review.

6. Brasil. Ministério da Saúde. Sistema Nacional de Transplantes. Lei $n^{\circ}$ 9.434/1997. Dispõe sobre Legislação sobre o sistema nacional de transplantes. Brasília: Ministério da Saúde, 2003b. [citado 2013 Set 20]. Disponível em: <http://dtr2001.saude.gov.br/ sas/dsra/legislacao.htm\#tipo >. Lei no 9.434/1997,

7. Brasil. Portaria $n^{\circ}$ 902/GM de 16/08/2000. [citado 2014 Set 17]. Disponível em: http://dtr2001.saude.gov.br/sas/PORTARIAS/ PORT2000/GM/GM-902.htm.

8. Brasil. Portaria 2600/2009 (Art. 47). Portaria GM/MS n 2600 de 21 de outubro de 2009 - Aprova o novo Regulamento Técnico do Sistema Nacional de Transplantes. [citado 2014 Jul 12]. Disponível em: http://sctransplantes.saude.sc.gov.br/index.php?option= com_content\&task=view\&id=172\&Itemid=215

9. Kamihira S, Nakasima S, Oyakawa Y, Moriuti Y, Ichimaru M, Okuda H, Kanamura M, Oota T. Transmission of human T cell lymphotropic virus type I by blood transfusion before and after mass screening of sera from seropositive donors. Vox Sang. 1987;52(1-2):43-4.

10. Fujikawa LS, Salahuddin SZ, Palestine AG, Masur H, Nussenblatt $\mathrm{RB}$, Gallo RC. Isolation of human T-lymphotropic virus type III from the tears of a patient with the acquired immunodeficiency syndrome. Lancet. 1985 Sep 7;2(8454):529-30.

11. European Centre for Disease Prevention and Control (ECDC) Technical Report. Risk assessment of HTLV-I/II transmission by tissue/cell transplantation. Part 2: Risks by tissue type, impact of processing and effectiveness of prevention measures. Stockholm: ECDC; 2012.
12. O'Day DM. The risk posed by HTLV-III-infected corneal donor tissue. Am J Ophthalmol. 1986;101(2):246-7.

13. Portela PC. Prevalência e diagnóstico laboratorial da infecção pelo vírus HTLV em gestantes em Mato Grosso do Sul, no período de 2002 a 2006. Brasília: UNB; 2008. 74p.

14. Thomas S, Klapper PE, Mutton KJ, Turner AJ, Tullo AB, Zambrano I, Carley F, Taylor A. Lack of vision, loss of sight: consequences of mandatory HTLV screening in corneal transplantation. Transpl Infect Dis. 2007;9(2):171-2.

15. Associação Pan-Americana De Bancos De Olhos. Trabalho sobre HTLV [citado 2014 out 08].

16. Brasil. Resolução - RDC 347/2003. Resolução - RDC No 347, de 02 de dezembro de 2003: Determina Normas Técnicas para o Funcionamento de Bancos de Olhos. [Acesso em 2014 Ago 8]. Disponível em: http://sctransplantes.saude.sc.gov.br/index2.php? option $=$ com_content $\&$ do_pdf $=1 \& \mathrm{id}=75$.

17. Dubord PJ, Evans GD, Macsai MS, Mannis MJ, Glasser DB, Strong DM, Noël L, Fehily D. Eye banking and corneal transplantation communicable adverse incidents: current status and project $\mathrm{NO}$ TIFY. Cornea. 2013;32(8):1155-66.

\section{Corresponding author:}

Gyanna Lys de Melo Moreira Montenegro

Transplantation Center of Paraíba - Ambulatory Benedita

Targino Maranhão

Av. Rio Grande do Sul, S/N, Bairro dos Estados - João Pessoa/PB

ZIP Code: 58.030-020

Phone: (83) 3244-6192 / 8845-3516

E-mail: gyannalys@hotmail.com 